\title{
Determinants of innovation and productivity in the service sector in Mexico
}

Claudia De Fuentes (corresponding author)

Sobey School of Business, Saint Mary's University

923 Robie Street, Halifax, Nova Scotia, Canada, B3H 3C3

e-mail: claudia.defuentes@smu.ca

Gabriela Dutrenit

Economics and Management of Innovation Program, Universidad Autonoma

Metropolitana-Xochimilco,

Calzada del Hueso 1100,

CP 04960 col. Villa Quietud Coyoacan, Mexico

e-mail: gabrieladutrenit@gmail.com

Fernando Santiago

School of International Development and Global Studies

Faculty of Social Sciences, University of Ottawa

PO Box 231

Social Sciences Building

120 University, Ottawa, Ontario, Canada, K1N 6N5

e-mail: rodriguez@merit.uni.edu

Natalia Gras

Economics and Management of Innovation Program, Universidad Autonoma

Metropolitana-Xochimilco,

Real de los Reyes 87 interior D-402,

CP 04330 col. Pueblo de los Reyes, Coyoacán, México

e-mail: nataliagras@gmail.com 


\title{
Determinants of innovation and productivity in the service sector in Mexico
}

\begin{abstract}
Based on survey data about firms in Mexico this paper investigates the determinants of innovation, and the linkages between innovation and productivity in the services sector. We applied a three-stage Crépon-Duguet-Mairesse (CDM) econometric model; the use of manufacturing firms as benchmark helped to better appreciate our findings. The paper identified that a series of structural, performance, and behavioral factors increase a firm's propensity to invest in innovation, but some differences arise between services and manufacturing firms. Intensive investment in innovation leads to superior innovation performance, while innovation output has a positive impact on labor productivity.
\end{abstract}

JEL classification: L8, O12, O14, O31, O33, O38, O40

Keywords: Innovation, Labor Productivity, Services, Manufacturing, Mexico.

\section{Introduction}

This paper stems from a larger research project on the determinants of innovation, and the linkages between innovation and labor productivity in the services sector in Latin America. In particular, we studied the case of firms in Mexico.

Three hypotheses guide our analysis. First, we expect services firms to actively engage in innovation (Drejer 2004; Hipp and Grupp 2005; Tacsir et al., 2011). Second, we expect services firms to innovate differently from manufacturing firms, the former would engage mostly in non-technological innovations (Tether, 2005). Third, increased innovation intensity should foster innovation outputs and thereby labor productivity (Crespi and Zuniga, 2012).

Previous studies based on the Crépon, Duguet and Mairesse -CDM- (1998) methodology have focused on manufacturing firms, while the study of services remains scant (Polder et al. 2009). The omission is unfortunate considering the increasing prominence of services in overall economic 
structures and employment of both developed and developing countries (Tether 2005, Tacsir et al. 2011). This paper contributes to the literature by looking explicitly at services firms, while results for manufacturing firms provide some benchmark to our discussion. For the sake of comparability with other country cases in the larger study, we adopted a conventional taxonomy of firms, namely hightechnology (high-tech) and low-technology (low-tech) manufacturing industries on the one hand, and Knowledge Intensive Business Services (KIBS) and traditional services on the other (Hipp and Grupp 2005, Tether and Takhar 2008, Castellacci 2008).

Two novel contributions of this paper include: (1) the testing of these hypotheses using a threestage econometric model based on the CDM methodology; an extensive literature review informed our CDM model specifications (Section 4); and (2) the inclusion of controls for different kinds of barriers to innovation in our explanatory variables. In line with previous studies based on CDM models, we found positive impacts of innovation intensity on innovation output, and on productivity for both services and manufacturing firms. Notwithstanding the low levels of innovation activity reported by Mexican firms, services firms tend to engage in innovation. Manufacturing firms tend to report more product or process innovations, while services firms tend to report more non-technological innovations. Our results suggest the pertinence for Mexican economic authorities to improve the conditions and incentives for a larger share of private firms to engage systematically in innovation as the basis for enhanced productivity and growth.

The remaining of this paper is as follows. Section 2 takes stock of available literature on innovation in services; Section 3 presents the main data source used in this study, namely one of the latest available Survey on Innovation and Technology Development (ESIDET 2010). Section 4 describes the CDM methodology, and the model specifications used for the empirical analysis. Section 5 presents our empirical analysis. Finally, section 6 concludes. 


\section{Three theoretical approaches to understand services innovation}

The services sector has become the largest contributor to gross domestic product (GDP) and employment in several developed and developing countries (Evangelista, 2000; Hauknes, 1996, Miles et al., 1995). In the case of Mexico, INEGI (2011) documents that during 2003-2011 while total GDP growth averaged $2.3 \%$ per annum, GDP in services expanded at an average rate of $2.8 \%$. This period recorded a steady increase in the contribution of services to total GDP, with a sustained decrease in the share of primary activities and a stagnating share of manufacturing. By 2011, services contributed $61.3 \%$ to GDP, while manufacturing represented $30.0 \%$, and the primary sector $3.5 \%$ (INEGI, 2011). As for the composition of GDP in services, $72.0 \%$ corresponds to traditional services ${ }^{1}, 10.0 \%$ to $\mathrm{KIBS}^{2}$, and the remaining $18.0 \%$ to other services ${ }^{3}$. This structure remains constant since 2003 , except for a slight increase in the share of traditional services. Similar dynamics is observed in job creation. Since 2003 services represent up to $62.0 \%$ of total employment in Mexico. Total employment grew at an average annual rate of $1.9 \%$, below the rate of $2.9 \%$ for employment in services. The sub-sectors that contributed the most to employment in services are Commerce (19.7\%), Diverse services ${ }^{4}(10.3 \%)$, Social services ${ }^{5}(8.3 \%)$, Temporary accommodation and the preparation of food and beverages $(6.2 \%)$, and Professional, financial and corporate services (5.6\%).

Arias-Ortiz et al. (2014) assert that the increased weigh of services in the productive structure of Latin America makes improving productivity in services a necessary ingredient to enhancing aggregate productivity in the region. However, evidence on the extent to which innovation in services can

\footnotetext{
${ }^{1}$ Traditional services include: trade, transportation, posting and storage, mass media information, financial services and insurance, real estate services and rental of property and intangible goods, recreational, cultural, and other recreational services, temporary accommodation and food and beverage preparation and financial intermediation services.

${ }^{2}$ KIBS include: scientific and technical services, management of corporate enterprises and support services for businesses, waste management and remedial services.

${ }^{3}$ Other Services include: educational services, health care and social assistance, and government activities.

${ }^{4}$ Diverse services include: real estate services and rental and intangible goods; recreational, cultural, other recreational services and other services except government activities.

${ }^{5}$ Social services include: Educational services and Health care and social assistance.
} 
contribute to improved productivity remains inconclusive, while studies in the field are at an early stage of development (Gallouj and Weinstein, 1997; Evangelista, 2000 and Drejer, 2004). Theoretical developments stem primarily from the study of innovation in manufacturing (Gallouj and Weinstein, 1997). The heterogeneity of services and their immaterial nature makes problematic the use of traditional indicators of innovation and productivity; this limits the capacity to track improvements or changes in product-services (quality level). These difficulties explain some complementary approaches to study innovation in services (Gallouj and Weinstein, 1997).

A first approach is called technology-based, or assimilation approach (Hauknes, 1996); it focuses on understanding the role of technology in services. Studies in this tradition build on the same conceptual framework, definitions and instruments used to research technological and product innovation in manufacturing. Djellal and Gallouj (2000) called subordinated surveys the use of innovation surveys applied to manufacturing firms, particularly Community Innovation Surveys (CIS), to study innovation in services. Previous studies have shed light on the impact of technology adoption in services, especially information and communication technologies, which expand on Barras' (1986, 1990) work on the reverse product cycle model. ${ }^{6}$ Also important is the development of taxonomies of specific technological trajectories for services (Miozzo and Soete 2001).

Gallouj and Weinstein (1997) acknowledge the theoretical value of Barras' contribution. Yet, they argue that more than an integrated theory of innovation in services, Barras $(1986,1990)$ contributes with a theory of technology diffusion from manufacturing to services. Djellal and Gallouj (2000) and Tether and Miles (2000) criticize the assimilation approach because it tends to ignore that innovation in services has specific characteristics; in addition to technological innovations, innovations encompass various forms of non-technological, including organizational and marketing innovations. In this

\footnotetext{
${ }^{6}$ Barras understood services innovation as a complementary process with other sectors of the economy, notably manufacturing. The model contends that the life cycle of services runs opposite to the cycle of industrial products; the development and subsequent adoption of the latter by services firms contribute to innovation in services.
} 
direction, Drejer (2004) and Tether and Howells (2007) argue that the indicators fail to capture potential differences resulting from other types of innovation in services.

A second approach defined as services-oriented, services-based or demarcation approach emphasizes the specificities of both innovation and production processes in services. It rejects the centrality of technological innovation (Gallouj and Weinstein, 1997; Hauknes, 1996; Drejer, 2004). Rather, it highlights the role of organizational innovation and knowledge-based services innovation; the importance of R\&D and "hard technologies" is lower than in manufacturing (Tether and Howells, 2007). Although the approach advocates the use of autonomous surveys, better tuned to understand innovation in services (Djellal and Gallouj, 2000), it is less concerned about comparing the specificities of innovation in services related to manufacturing. Consequently, a major shortcoming is the potential for errors in the inference of what is or what is not specific to innovation in services (Drejer, 2004). The heterogeneous nature of services implies that even if innovation in certain services may show strong similarities with innovation in manufacturing, some others clearly show certain specific characteristics (Hauknes, 1996).

Today, the literature on innovation in services recognizes the importance, interactions and complementarities between technological and non-technological innovation -especially organizational (Tether and Howells, 2007). This view underpins a third approach to innovation in services, what Hauknes (1996) called integrated or synthesis approach, which highlights the growing complexity and multidimensional nature of innovation in services and manufacturing. Arguably, the complementarities and convergence between the production of goods and services implies that understanding innovation in services helps to better understand innovation elsewhere in the economy. Research is shifting focus from technology to knowledge and, from the study of individual firms to value chains or networks; services and manufacturing are interconnected parts in a system. For instance, KIBS for example can be seen as technological or knowledge intermediaries in innovation systems (Miles et al., 1995). 
The integrative approach is relatively recent, still not applied in many innovation surveys (Drejer, 2004). Relevant contributions include Gallouj and Weinstein (1997), Coombs and Miles (2000), Hollenstein (2003), Drejer (2004), Hipp and Grupp (2005), Leiponen and Drejer (2007), Castellacci (2008), and Peneder (2010). This paper follows an integrated approach; it looks at the effect of innovation intensity on innovation output, and the effect of innovation output on productivity for manufacturing and services firms based on a common analytical framework.

\section{Data Sources}

This study builds on the Mexican's Survey on Innovation and Technology Development (ESIDET) conducted by the National Institute of Geography, Informatics and Statistics (INEGI by its Spanish acronym) on behalf of the country's Council for Science and Technology (CONACYT). ESIDET includes a section of innovation questions based on the Oslo Manual. We worked with preliminary data from the event 2010, with information for the period 2008-2009. The unit of analysis is the firm; its geographical coverage is national, while sectoral coverage includes manufacturing and services. ESIDET uses a stratified random sample for each of the industries according to the OECD classification. The raw data consists of a representative sample of 4,156 firms: manufacturing $(2,455)$ and services $(1,701)$. It could be some positive bias towards large manufacturing firms as almost $78 \%$ of the firms in the sample are large firms with more than 501 employees. $^{7}$ A group of firms is considered a forced inclusion: those with 751 or more employees, and a set of 1,271 firms registered by CONACYT as eligible to receive public funding in support of R\&D or other innovation-related activities.

Based on Mohnen et al. (2006) we performed an extensive cleaning for outliers and inconsistencies in the dataset (e.g. firms with less than 20 employees, with missing industry affiliation,

\footnotetext{
${ }^{7}$ INEGI applies expansion factors which produce a distribution of firms that better reflects the larger share of services firms in the total population of firms.
} 
with expenditures in innovation in excess of $100 \%$ of sales, and with $\mathrm{R} \& \mathrm{D} / \mathrm{sales}$ ratios in excess of $80 \%$ ). Our usable sample contains 1,844 manufacturing and 874 services firms. Based on the International Standard Industrial Classification (ISIC) Rev. 3.1. ${ }^{8}$, we classified these firms in high-tech $(24,29,30,31,32,33,34$ and 35 , except 351) and low-tech manufacturing $(15,16,17,18,19,20,21$, 22, 23, 25, 26, 27, 28, 351, 36, and 37), KIBS (72, 73 and 74, except 7492, 7493 and 7499) and traditional services $(45,50,51,52,55,60,61,62,63,64,65,66,67,70,71$ and 7492, 7493, and 7499).

In addition to information on innovation performance, ESIDET 2010 identifies firm's general characteristics including firm size, industry, exports, group affiliation, foreign direct investment (FDI), human resources, R\&D performance, expenditure in scientific and technological services, and technology transfer. It also contains information about participation in publicly funded programs in support of $R \& D$ and innovation, international cooperation, and the firms' perception on factors that motivate/hinder innovation.

\section{Econometric model}

\subsection{The models}

Models based on the CDM methodology have proven useful to identify and test the determinants of innovation and, by extension, the effects of innovation outputs on manufacturing productivity (Crespi and Zuñiga 2012). A challenge to apply the methodology to study services firms is that it tends to rely on $R \& D$ as a proxy to identify innovative firms. However the literature indicates that for services, R\&D is not the preferred mechanism underpinning innovation (OECD, 2009; Polder et al. 2009). Services firms may find it difficult to track and record R\&D expenditures, even consider the funds used for innovation in the same way as it is understood in manufacturing contexts. To overcome this

\footnotetext{
${ }^{8}$ ESIDET 2010 follows the North American Industry Classification System (NAICS) 2007, not fully compatible with standard industry classifications based on a firm's technology intensity. INEGI provides the equivalence between ISIC Rev. 3.1 and NAICS 2007. The NAICS codes for the KIBS industries included in this study where identified based on 'The Use of Knowledge-Intensive Business Services in SME Manufacturing Firms in Quebec: Performance Diagnosis and Drivers of Innovation by Sector and Region', http://www.dec-ced.gc.ca/eng/publications/economic/studies/2012/265/page-4.html
} 
challenge, our empirical analysis incorporated, in addition to $\mathrm{R} \& \mathrm{D}$, data about other seven innovation activities as reported in ESIDET (2010), namely, the purchase of machinery and equipment, the acquisition of other external technologies, the provision of training, the processes underpinning the launch of innovations into the market, industrial design or prototyping of new or improved processes or products, the purchase of software, and the logistics supporting introduction of new services or new/improved product delivery systems.

We performed a three-stage Heckman (1978) model where the first stage explores the main factors underpinning a firm's decision to invest in innovation, and the intensity of the investment in innovation. This first stage corrects for selection bias as not all firms engage in innovation. The second stage is the knowledge production function and focuses on innovation outputs, measured as product or process innovations. Finally, the third stage studies the effects of innovation on productivity. Our model specifications build on Crespi and Zuñiga (2012), who analyzed the determinants of innovation and its impact on labor productivity in manufacturing for a set of six Latin American countries. We incorporated additional variables based on Benavente (2002), Griffit et al. (2006), Mohnen et al. (2006), and Polder et al. (2009).

The Heckman model includes two equations: the selection equation (Eq1), which explores the main determinants of innovation, and the outcome equation (Eq1.1) that indicates the intensity of investment in innovation. The dependent variable for Eq1 (dummyEXCAPi) is a dummy that equals 1 if the firm performs at least one of eight possible types of innovation activities. The set $X_{i}$ in Eq1 includes firm size, FDI, group affiliation, previous export experience, previous patent application, access to public financial support, and barriers to innovation. The error term indicates the effect of omitted variables. Standard errors are estimated by bootstrapping:

$$
\text { (Eq1) dummyEXCAP } P_{i}=X_{i} b, j_{i 1}, \ldots j_{i n}+e_{i}
$$


The dependent variable for the outcome equation in stage $1\left(\right.$ Eq1.1) $\left(\log E X C A P_{i}\right)$ is the $\operatorname{logarithm}$ of the firm's investment, per employee, in innovation. Because the vector of explanatory variables $\left(X_{i i}\right)$ includes the predicted variables for equation 1, we used bootstrapping to correct for the standard errors:

$$
\text { (Eq1.1) } \log E X C A P_{i}=X_{i i} b, j_{i 1}, \ldots j_{i n}+e_{i}
$$

The second stage introduces an innovation production function (Eq1.2) where a firm's innovation output is measured by the introduction of product or process innovations (innov_dummy). The independent variables include lagged variables for some control, such as firm size to account for innovation time frames. We also use the predictor from equation 1.1 (EXCAP_eq11). Standard errors are estimated by bootstrapping.

$$
(\mathrm{Eq1.2}) \text { innov_dummy }{ }_{i}=E X C A P \_e q 11_{i}+x_{i} b, j_{i 1}, \ldots j_{i n}+e_{i}
$$

The third stage of the model, equation Eq1.3 captures the impact of innovation on firm's performance in terms of labor productivity -sales per employee expressed in logarithms. The independent variables include the predictors from Eq1.2. ${ }^{9}$ Standard errors are estimated by bootstrapping.

$$
\text { (Eq1.3) logproductivity09 }{ }_{i}=\text { innov_eq12 }{ }_{i}+a_{i} c_{i}, j_{i 1}, \ldots j_{\text {in }}+e_{i}
$$

We computed this three-stage model on our complete sample of manufacturing and services firms. To better capture the behavior of services and manufacturing firms we computed three different model specifications. Model 1 includes 16 industry dummies for manufacturing and services. Model 2 is computed for manufacturing only, and model 3 is computed for services only.

\subsection{Variables}

The independent variables in equation 1 and 1.1 are associated with firm size, as large firms are more prone to capture economies of scale related to production and R\&D; they also benefit from a larger

\footnotetext{
${ }^{9} \mathrm{We}$ also performed a robustness analysis by including in the equation the predictors from Eq1.1 as expressed below. (1.3.1) logproductivity09i $=E X C A P \_e q 11 i+a i c i, j i 1, \ldots j i n+e i$
} 
pool of human resources, and are more likely to engage in innovation. In Eq1 size is measured as a continuous variable that indicates the number of employees in 2008, expressed in logarithm. The variable on firm size is excluded from the set of explanatory variables in Eq. 1.1, as innovation investment is already scaled for size. We expect foreign ownership to positively influence innovation decisions and innovation intensity. We used a dummy variable for ownership that takes the value of 1 if the firm reports FDI in its social capital. Patents are proxy for the firm's intellectual property strategy, and patents are positively correlated with innovation efforts (Crespi and Zúñiga, 2012). In our study, patent is a dummy variable that indicates if the firm filed for patents during 2008. Participation in export markets encourages innovation, we capture this by introducing a dummy variable that takes the value of 1 if the firm exported in 2008 to control for potential endogeneity problems.

It is recognised the importance of public funds that supplement a firm's investment in R\&D, as they can enhance the decision to innovate and the innovation intensity. Based on Griffit et al. (2006) and Crespi and Zuniga (2012), the use of public funds for innovation entered both Eq1 and Eq1.1 in our model. The variable is a dummy that equals 1 if the firm used any form of public funds from a list of funds that support innovation. In regards to collaboration for innovation, Mohnen et al. (2006), Griffit et al. (2006), and Crespi and Zúñiga (2012) document that sharing cost and knowledge through collaboration has positive effects on innovation. We used a dummy variable that equals one if the firm collaborated with research centers, universities or the private sector to perform innovation. Collaboration for innovation only entered Eq. 1.1. Based on Crespi and Zúñiga (2012) we included three dummy variables denoting the most important sources of information, as perceived by the firm, which stimulate innovation: market, scientific, and public sources of information. These different dummy entered Eq1.1 only.

The perception of barriers to innovation has important effects on a firm's decision to innovate (Mohnen et al. 2006; Mairesse and Mohnen 2010; Uzagalieva, Kocenda and Menezes, 2012). However 
barriers to innovation are challenging to interpret depending on the firm's degree of engagement in innovation. The more firms engage in innovation, the better they are at identifying and characterizing the importance of the barriers they encounter during the innovation process (Galia and Legros 2004; Mohnen et al. 2008; Savignac 2008). None of the existing empirical studies in the CDM tradition has included barriers to innovation as independent variables affecting either the decision to engage in innovation or the innovation intensity of a firm. Based on D'Este et al. (2012) we included four dummy variables that account for: cost, knowledge, market, and regulation barriers in both Eq1. and Eq1.1. In Eq1 the effect would be one of deterring engagement in innovation; in Eq1.1, the effect would reveal the perceived importance of specific barriers for the firm.

Firms that are part of a larger business group are expected to benefit from the group knowledge spillovers, and potential access to a larger pool of financial and human resources needed for innovation. Following Mohnen et al. (2006) and Polder et al. (2009), we included group affiliation as a dummy variable equal to 1 if the firm is part of a group. We also incorporated a dummy variable that equals 1 if the firm is headquarter of a group, and zero otherwise. We included these two variables in both, Eq1. and Eq1.1.

The independent variables in Eq1.2 are firm size, ownership, and exports. In Eq1.2 we used the number of employees in 2009 instead of 2008 to account for the lagged time from investment in innovation to obtain innovation outcomes. We included the predicted value of innovation intensity from the output equation in stage one (EXCAP_eq11), and controlled by industry dummies.

The variable for productivity is the logarithm of average sales per employee. The independent variables refer to firm size, and non-technological innovation that is included as a dummy variable equal to 1 if the firm has introduced any market or organizational innovations. In this line, Crespi and Zuñiga (2012) found an important effect of non-technological innovation on firm's productivity and mention the existence of complementarities between technological and non-technological innovation. 
We included capital per employee (Polder et al. 2009; Crespi and Zuñiga 2012), and the existence of a technical department of engineers (Benavente 2006) reflecting skilled technical labor. Following the same reasoning, Eq1.3 used the number of employees and capital in 2009. We included the predicted values from innovation output (innov_eq12), and controlled by industry dummies.

\section{Empirical results}

\subsection{Descriptive statistics}

Manufacturing firms represent approximately two thirds of firms in our sample, the remaining being in services (Table 1). Low-tech manufacturing firms and those in traditional services constitute the majority of firms. Some $41 \%$ of firms belong to a larger group, with manufacturing being the more frequently involved in some kind of conglomerate. As for capital ownership, a third of our firms reported FDI participation; manufacturing firms, particularly in high-tech, more likely report FDI. By contrast, KIBS firms reported the lowest share of FDI.

\section{[TABLE 1 ABOUT HERE]}

Services firms provide more employment than manufacturing firms, particularly in traditional sectors. Accordingly, manufacturing firms report median sales per employee, which are higher than those of services firms. Traditional services record the lowest median sales per worker.

In the period $2008-2009$ only $27.2 \%$ of firms in our sample performed some kind of innovation activities. Firms, in high-tech and KIBS, were the most active and dynamic at innovation; about 22.6\% of high-tech firms reported innovations in product or process; while $18.1 \%$ of KIBS reported innovations. The opposite can be said of traditional services, which reported only $4.7 \%$. The most significant obstacles to innovation refer to the cost of innovation and excessive economic risks. Insufficient financial capacity and regulatory barriers follow closely. Barriers related to insufficient manpower and organizational rigidities received the lowest ranking. 


\subsection{Econometric analysis}

\subsubsection{The decision to invest in innovation and the intensity of innovation expenditure}

Table 2 presents estimated marginal effects for the decision to invest (Eq1.) and for innovation intensity (Eq1.1), respectively. The results uncover interesting similarities and differences between services and manufacturing.

\section{[TABLE 2 ABOUT HERE]}

We consider the effect of capital ownership and group affiliation in both Eq1 and Eq1.1, and firm size only in the selection equation. Foreign ownership in general has a negative effect on firms' decision to invest in innovation. The marginal effect is 0.186 for the complete sample, and 0.208 for manufacturing firms. Foreign ownership does not report significant impacts on innovation intensity. Our findings differ from those for manufacturing firms in Argentina, Panama and Uruguay, as reported by Crespi and Zuñiga (2012). Differences can be explained by the fact that multinational companies seldom invest in R\&D in Mexico, whenever they do so it is to adapt existing products to the local market. Similar to Polder (2009), we found that firms part of a group more likely report positive effects on the decision to innovate for manufacturing, but our results did not report a significant effect for services firms. However, once the firm engages in innovation, group affiliation seems not to have significant effects on innovation intensity. Our results show that headquarters have positive effects on the decision to innovate, but a negative effect on innovation intensity for manufacturing. The positive results on the decision to innovate might indicate that firms belonging to a group and headquarters have easier access to financial and human resources, as compared to stand-alone firms.

Previous studies based on the CDM methodology report that large firms more likely invest in innovation (Benavente 2006; Griffith et al. 2006; Crespi and Zuñiga 2012). However, our results show that firm size has a negative effect on the decision to innovate for manufacturing, and it has no significant effect for services. This result is somehow at odds with the literature, as large firms usually 
enjoy a larger pool of financial and human resources to deploy innovation activities. During the modeling process we input firm size in logarithm and, in an alternative way based on Griffith et al. (2006) in the form of four dummy variables, with fairly consistent results.

The use of the variable of exports for 2008 introduced some lag as a way to control for endogeneity problems; our results suggest that previous export experience has a positive and significant influence on the decision to innovate for services and manufacturing. Having experience filing for patents showed a positive effect on the decision to innovate and innovation intensity for manufacturing, but not for services. Filing for patents indicates that the firm appropriates the innovation effort, and that it possesses an important pool of knowledge with positive impact on future decisions to innovate.

We found that factors such as access to public funding to foster innovation matter for both the decision to innovate and the intensity of innovation investment for services and manufacturing. Once firms engage in innovation, public funds have a slightly higher effect on services firms than on manufacturing firms. Similar results were obtained by Polder (2009) for manufacturing and services.

Cooperation to innovate and access to information useful for innovation were included only in Eq1.1. Cooperation for innovation with universities, research centers, and other firms positively affects innovation intensity for services and manufacturing; this suggests the possible benefit associated with access to different, complementary resources and the opportunity to minimize risks. Similar results were found by Polder (2009). Estimates for variables on the use of different sources of information were not significant for either sector, which points at the limited knowledge exchange among actors in Latin American innovation systems.

We also included barriers to innovation in equations Eq1. and Eq1.2. Our results indicate that only barriers associated with cost, which include economic risk, innovation cost and lack of finance, have positive and significant effects on the decision to innovate for both services and manufacturing firms. We need to identify these results with care as Mohnen et al. (2006) indicated that firms that 
engage in innovation activities might be better able to perceive barriers than firms that do not engage in innovation activities at all.

\subsubsection{The impact of innovation investment on the probability of technological innovation}

We now turn to our estimates related to the knowledge production function (Eq1.2); marginal effects are reported in Table 3. We found that the coefficient for innovation intensity is positive and significant for both, services (0.02) and manufacturing firms (0.16). This result confirms those by Crespi and Zúñiga (2012), Griffith et al. (2006), Raffo, Lhuillery and Miotti (2008) and Uzagalieva, Kocenda, and Menezes (2012), and indicates that firms with higher innovation intensity per employee show higher probability to introduce at least one product or process innovation.

\section{[TABLE 3 ABOUT HERE]}

Contrary to Cuadros and Alguacil (2014) and Uzagalieva, Kocenda and Menezes (2012), who found a positively relationship between FDI and innovation efforts in the manufacturing sector, no significant effects were identified for foreign ownership on the knowledge production function neither for manufacturing nor services, the same result was found for firm size. Other factors such as previous export experience are positive and significant in the knowledge production function (manufacturing of 0.07 and services of 0.04 ); other authors found contradictory results for different countries.

\subsubsection{Impact of innovation on productivity}

Equation 1.3 served to estimate the effects of innovation output on productivity in terms of sales per employee. Table 4 reports the results in elasticities or semi-elasticities, as the dependent variable is reported like the log of sales per employee. Our results are consistent with previous studies for Latin America (Crespi and Zuñiga 2012) and Europe (Griffith et al. 2006), and show a positive and significant impact of innovation performance on firm's productivity across the three model specifications. The semi-elasticity of innovation output for services is 1.073 , and 1.176 for manufacturing firms. In other words, the introduction of innovation is associated with important labor 
productivity gains for both sectors. The magnitude of these coefficients is similar to those by Crespi and Zuñiga (2012), who also used dummy variables for the introduction of technological innovations.

\section{[TABLE 4 ABOUT HERE]}

Our results identify negative effects of firm size on productivity. Crespi and Zúñiga (2012) found similar results in the case of Costa Rica. Regarding the influence of non-technological innovation on productivity, our results show a positive and significant effect for services $(0.205)$ and manufacturing (0.184). This result confirms those by Crespi and Zúñiga (2012) and points out the existence of complementarities between technological and non-technological innovation that contribute to firm's productivity. Regarding the effect of having a technical department of engineers, our results show a positive effect on productivity for services and manufacturing firms, although the effect is low.

\section{Conclusions}

This paper explored the determinants of innovation and the linkages between innovation and productivity in Mexico, particular emphasis was placed on the performance of services firms. Our findings indicate that innovation intensity has a strong impact on innovation output, while innovation output has a high impact on firm's productivity. These results are consistent with those by Crépon, Duguet and Mairesse (1998), Crespi and Zúñiga (2012) and Griffit et al. (2006).

We confirmed the importance of several factors for both decisions to innovate and innovation intensity. We were able to corroborate differences between manufacturing and services firms in terms of determinants for innovation, in innovation outputs and the effects of innovation on productivity in the Mexican case. Understanding the determinants to engage in innovation activities and innovation intensity is necessary to inform strategies that foster productivity of firms. Moreover, as stressed by Arias-Ortiz et al. (2014), boosting productivity in services should contribute to enhancing the country's aggregate productivity. 
Export experience and filing for patents play a significant role for engaging in innovation activities for services firms, while only export experience seems to play a significant role in the case of manufacturing firms. Following Mohnen et al. (2006)'s concern about potential endogeneity problems of including exports, in our model, inclusion of exports as a lagged variable tried to capture the importance of export experience as determinant of the decision to innovate, and at the same time, try to control for endogeneity.

Access to public funds for innovation turned out important to underpin decisions to invest in innovation for both, manufacturing and services, but once services firms engage in innovation activities, access to public funds has a higher effect on their innovation intensity. This finding suggests the pertinence of carefully designed policy interventions in support of innovation better tuned to the characteristics of services firms. Policy interventions should help firms address internal constraints to innovation, while at the same time, facilitate adoption of more active innovation strategies, which incorporate establishment of networks, and more critical use of scientific sources of information. Moreover, publicly supported programs need to recognize the importance of public sources of information underpinning innovation among services and manufacturing firms, as our results indicate that market, universities and centres, and public sources of information have no effect on firm's innovation intensity. In the same vein, Crespi and Zuñiga (2012) indicate that firms in Latin America fail to take advantage of public sources of information that can bring a positive effect on their innovation performance and productivity.

Our findings suggest that manufacturing firms have more mature innovation processes than services firms. However, we found evidence that these latter engage in innovation that answers positively our first research hypothesis. Moreover, in line with our second hypothesis, we found differences within sectors. Previous analysis reported visible differences in the kind of innovation activities performed by different types of firms, for example manufacturing firms tend to predominately 
innovate through purchases of machinery and equipment, R\&D, industrial design or prototyping, and the purchase of software (Dutrénit et al., 2013). By contrast, services tend to be more active in the provision of training linked to innovation.

We found no perceptible effects from inclusion of different kinds of barriers to innovation, on firms' innovation intensity. This result might lend some support to literature on barriers to innovation, which suggest that firms need to engage, at least to a certain extent, in innovation in order to develop the ability to identify the obstacles to innovation (Mohnen et al. 2006; D'Este et al. 2012). The limited engagement in innovation recorded by both manufacturing and services firms in Mexico may indicate their poor capacity to characterize the factors that constraint innovation performance.

Finally, this study has several limitations, such as the absence of panel data that can provide a better analysis regarding the drivers for innovation and its effect on innovation output and productivity. We are exploring the differences between services and manufacturing, but we have provided some first insights of the determinants of innovation in services firms in Mexico. Further work can draw more finely on the integrative approach, differentiate between the types of innovation activities, and distinguish them between tangibles and intangibles to observe the effect of types of activities on the innovation output and productivity.

\section{Acknowledgements}

We acknowledge funding and support from the Competitiveness and Innovation Division of the Inter-American Development Bank. We are also indebted to Conacyt for facilitating access to the data used in this study. We have benefited enormously from comments by four anonymous reviewers to this journal.

\section{References}

Arias-Ortiz, E., G. Crespi, A. Rasteletti and F. Vargas. 2014. "Productivity in Services in Latin America and the Caribbean". IDB, Discussion Paper, No. IDB-DP-346, Washington. 
Barras, R. 1986. "Towards a theory of innovation in Services.” Research Policy 15: 161-173.

Barras, R. 1990. "Interactive innovation in financial and business Services: The vanguard of the services revolution." Research Policy, 19(3): 215-237.

Benavente, J. M. 2006. "The Role of Research and Innovation in Promoting Productivity in Chile." Economics of Innovation and New Technology 15(4-5): 301-315.

Castellacci, F. 2008. “Technological paradigms, regimes and trajectories: Manufacturing and services industries in a new taxonomy of sectoral patterns of innovation.” Research Policy 37: 978-994.

Coombs, R. and I. Miles. 2000. Innovation measurement and Services: the new problematique. In: Metcalfe, J.S. and I. Miles (Eds.), Innovation Systems in the Service Economy. Measurements and Case Study Analysis. Kluwer, Boston, pp. 85-103.

Crépon, B., E. Duguet, and J. Mairesse. 1998. "Research, Innovation And Productivity: An Econometric Analysis At The Firm Level." Economics of Innovation and New Technology 7(2): 115-158.

Crespi, G. and P. Zuñiga. 2012. "Innovation and Productivity: Evidence from Six Latin American Countries." World Development 40(2): 273-290.

Cuadros, A. and M. Alguacil. 2014. "Productivity Spillovers Through Foreign Transactions: The Role of Sector Composition and Local Conditions." Emerging Markets Finance \& Trade 50(2): 75-88.

D’Este, P., S. Iammarino, M. Savona and N. von Tunzelmann. 2012. "What hampers innovation? Revealed barriers versus deterring barriers." Research Policy 41(2): 482-488.

Djellal, F. and F. Gallouj. 2000. "Innovation surveys for services industries: a review". Paper presented at the DG Enterprise Conference on Innovation and Enterprise Creation: Statistics and Indicators. Sophia Antipolis, France, November 2000.

Drejer, I. 2004. “Identifying innovation in surveys of Services: a Schumpeterian perspective”. Research Policy 33(3): 551-562.

Dutrénit, G., C. De Fuentes, F. Santiago, A. Torres and N. Gras (2013), "Innovation and Productivity in the Service Sector The Case of Mexico”, IDB, Discussion Paper, No. IDB-DP-293, Washington.

Evangelista, R. 2000. "Sectoral patterns of technological change in Services.” Economics of Innovation and New Technologies 9: 183-221.

Galia, F. and D. Legros. 2004. "Complementarities between obstacles to innovation: evidence from France.” Research Policy 33(8): 1185-1199.

Gallouj, F. and O. Weinstein. 1997. “Innovation in Services.” Research Policy 26(4-5): 537-556. 
Griffith, R., E. Huergo, J. Mairesse and B. Peters. 2006. "Innovation and Productivity across Four European Countries." Oxford Review of Economic Policy 22(4): 483-498.

Hauknes, J. 1996. “Innovation in the Service Economy. STEP rapport/report, Oslo, December 1996

Heckman, J. 1978. "Dummy endogenous variables in a simultaneous equation system”. Econometrica. 47: 153-161.

Hipp, C. and H. Grupp. 2005. "Innovation in the services sector: the demand for servicespecific innovation measurement concepts and typologies." Research Policy 34: 517-535.

Hollenstein, H. 2003. "Innovation modes in the Swiss services sector: a cluster analysis based on firmslevel data."Research Policy 32: 845-863.

Leiponen, A. and I. Drejer. 2007. "What exactly are technological regimes? Intra-industry heterogeneity in the organization of innovation activities." Research Policy 36(8): 1221-1238.

Mairesse, J. and P. Mohnen. 2010. "Using Innovation Surveys for Econometric Analysis.” In: Hall, B. and Rosenberg, N. (Eds), Handbook of the Economics of Innovation, North-Holland, Volume 2, Pages 1129-1155.

Miles, I., N. Kastrinos, R. H. Bilderbeek and P. den Hertog. 1995. "Knowledge-intensive business services- Users, carriers and sources of innovation”. EIMS Publications no. 15, EC 1995

Miozzo, M. and L. Soete. 2001. "Internationalization of Services: A technological Perspective." Technological Forecasting and Social Change 67: 159-185.

Mohnen, P., F. C. Palm, S. Schim Van Der Loeff, and A. Tiwari 2008. "Financial Constraints and Other Obstacles: are they a Threat to Innovation Activity?” De Economist 156(2): 201-214.

Mohnen, P., J. Mairesse, and M. Dagenais. 2006. Innovativity: A comparison across seven European countries." Economics of Innovation and New Technology 15(4-5): 391-413.

OECD. 2009. Innovation in Firms: A Microeconomic Perspective. Paris, France: Organization for Economic Cooperation and Development

Peneder, M. 2010. "Technological regimes and the variety of innovation behaviour: creating integrated taxonomies of firms and sectors."Research Policy 39: 323-334.

Polder, M., G. v. Leeuwen, P. Mohnen, and W. Raymond. 2009. "Productivity effects of innovation modes." MPRA Paper.

Raffo, J., S. Lhuillery and L. Miotti. 2008. "Northern and Southern Innovativity: A Comparison across European and Latin American Countries.” European Journal of Development Research 20(2): 219239. 
Savignac, F. 2008. "Impact of financial constraints on innovation: What can be learned from a direct measure?" Economics of Innovation and New Technologies 17(6): 553-569.

Tacsir, E., C. Guaipatin et al. 2011. "Innovation in Services: The Hard Case for Latin America and the Caribbean.” Discussion Paper.

Tether, B. 2005. "Do Services Innovate (Differently)? Insights from the European Innobarometer Survey". Industry and Innovation 12(2): Special Issue: Innovation in Services. 153-184.

Tether, B. and A. Takhar. 2008. "The organisational-cooperation mode of innovation and its prominence amongst European services firms.” Research Policy 37: 720-739.

Tether, B. and C. Hipp. 2000. Competition and innovation amongst knowledge-intensive and other services firms: evidence from Germany. In: Andersen, B., J. Howells, R. Hull, I. Miles and J. Roberts (Eds.), Knowledge and innovation in the New Service Economy. Edward Elgar Publishing, Cheltenham, pp. 49-67.

Tether, B. and J. Howells. 2007. "Changing Understanding in Innovation in Services.” DTI. Innovation in Services. Occasional Paper No 9, June; Department of Trade and Industry, UK.

Tether, B. and I. Miles. 2000. "Surveying Innovation in services- Measurement and Policy Interpretation Issues." Paper presented at the DG Enterprise Conference on Innovation and Enterprise Creation: Statistics and Indicators. Sophia Antipolis, France, November 2000.

Uzagalieva, A., Kocenda, E. and Menezes, A. 2012. "Technological Innovation in New EU Markets." Emerging Markets Finance \& Trade 48(5): 48-56.

Websites:

INEGI: Conversión SCIAN 2002_2007, Mexico.

https://docs.google.com/viewer?url=http\%3A\%2F\%2Fwww.inegi.org.mx\%2Fsistemas\%2Fscia n\%2Fcontenidos\%2FTablas\%2520comparativas\%2FTabla\%2520Comparativa\%2520VIII.xls. UNSTATS United Nations Statistics Division, Correspondencia entre SCIAN 2002 (México) y ISIC Rev.3.1. http://unstats.un.org/unsd/cr/registry/regso.asp?Ci=47\&Lg=3. 
Table 1: Descriptive Statistics

\begin{tabular}{|c|c|c|c|c|c|c|c|}
\hline Variables & $\begin{array}{l}\text { Complete } \\
\text { sample }\end{array}$ & $\begin{array}{l}\text { Manufact } \\
\text { uring }\end{array}$ & High-tech & Low tech & Services & KIBS & Traditional \\
\hline Number of firms & 2718 & 1844 & 722 & 1122 & 874 & 149 & 725 \\
\hline Percentage of firms with innovative activities & 27.2 & 31.0 & 38.5 & 24.0 & 19.1 & 40.9 & 14.6 \\
\hline Average expenditure on innovation activities & $19,544.55$ & $24,204.42$ & $34,360.38$ & $17,669.13$ & $9,712.96$ & $13,954.94$ & $8,841.16$ \\
\hline Average expenditure on innovation activities per employees & 19.25 & 23.23 & 38.79 & 13.22 & 10.85 & 39.69 & 4.92 \\
\hline Percentage firms that innovate product or process & 14.3 & 17.7 & 22.6 & 13.4 & 7.0 & 18.1 & 4.7 \\
\hline Average productivity (sales/employee) in 2009 & 969.25 & 1045.55 & 1346.59 & 851.83 & 808.29 & 836.70 & 802.45 \\
\hline Average employees in 2008 & 1598.68 & 1332.96 & 1353.04 & 1320.04 & 2159.31 & 1223.51 & 2351.64 \\
\hline Average employees in 2009 & 1549.15 & 1257.74 & 1210.66 & 1288.04 & 2163.98 & 1266.13 & 2348.50 \\
\hline Percentage firms with FDI & 29.1 & 37.5 & 61.2 & 20.4 & 11.3 & 11.4 & 11.3 \\
\hline Percent of firms belonging to a group & 41.4 & 46.3 & 64.5 & 31.8 & 31.0 & 21.5 & 33.0 \\
\hline Percent of firms headquarters & 5.4 & 5.6 & 7.8 & 3.8 & 5.1 & 4.0 & 5.4 \\
\hline Percentage of exporting firms in 2008 & 41.4 & 56.2 & 75.6 & 40.2 & 10.1 & 19.5 & 8.1 \\
\hline Percentage of exporting firms in 2009 & 41.6 & 56.5 & 75.1 & 40.8 & 10.4 & 19.5 & 8.6 \\
\hline Average of export/sales 2008 & 0.248 & 0.345 & 0.524 & 0.229 & 0.045 & 0.050 & 0.044 \\
\hline Average of export/sales 2009 & 0.249 & 0.346 & 0.522 & 0.233 & 0.045 & 0.049 & 0.044 \\
\hline Percentage of firms filing patents & 1.7 & 2.2 & 2.8 & 1.6 & 0.6 & 2.0 & 0.3 \\
\hline Percentage of firms with public financial support & 14.8 & 17.0 & 21.5 & 12.9 & 10.1 & 25.5 & 6.9 \\
\hline Percentage of firms doing cooperation in innovation & 4.0 & 4.6 & 6.2 & 3.3 & 2.7 & 7.4 & 1.8 \\
\hline Percentage of firms that use market sources of information & 64.7 & 67.1 & 71.9 & 58.8 & 59.6 & 57.0 & 60.1 \\
\hline $\begin{array}{l}\text { Percentage of firms that use scientific sources of } \\
\text { information }\end{array}$ & 21.1 & 21.9 & 25.6 & 17.9 & 19.3 & 24.8 & 18.2 \\
\hline Percentage of firms that use public sources of information & 40.3 & 42.2 & 44.2 & 37.6 & 36.4 & 39.6 & 35.7 \\
\hline Percentage of firms with non-technological innovations & 51.9 & 52.5 & 54.0 & 47.3 & 50.8 & 61.1 & 48.7 \\
\hline Percentage of firms that report cost barriers & 65.3 & 67.7 & 68.0 & 62.0 & 60.3 & 64.4 & 59.4 \\
\hline Percentage of firms that report knowledge barriers & 34.0 & 34.2 & 35.2 & 30.8 & 33.8 & 26.8 & 35.2 \\
\hline Percentage of firms that report market barriers & 39.6 & 39.9 & 40.4 & 36.3 & 38.9 & 40.9 & 38.5 \\
\hline Percentage of firms that report regulation barriers & 35.9 & 36.1 & 37.1 & 32.6 & 35.5 & 28.9 & 36.8 \\
\hline Average Capital (physical capital per employee) 2009 & 283.33 & 157.18 & 289.21 & 72.22 & 549.48 & 279.16 & 605.04 \\
\hline Average of engineers working in technical department & 10.57 & 11.51 & 16.68 & 8.18 & 8.59 & 35.66 & 3.02 \\
\hline Average of $R \& D$ expenditure/sales & 0.002 & 0.002 & 0.003 & 0.001 & 0.002 & 0.008 & 0.001 \\
\hline
\end{tabular}

Table 2: Decision to invest in innovation and the intensity of innovation expenditure

Dep. Variable $\quad$ Engage in innovation activities (dummy) (Eq1.)

Innovation Intensity (Eq1.1) 


\begin{tabular}{|c|c|c|c|c|c|c|}
\hline Sample & Complete & Manufacturing & Services & Complete & Manufacturing & Services \\
\hline Size 2008 & $\begin{array}{l}-0.039 \\
(0.027)\end{array}$ & $\begin{array}{c}-0.059^{*} \\
(0.034)\end{array}$ & $\begin{array}{l}-0.001 \\
(0.031)\end{array}$ & & & \\
\hline Firm FDI & $\begin{array}{c}-0.186^{* * *} \\
(0.067)\end{array}$ & $\begin{array}{c}-0.208^{* *} \\
(0.106)\end{array}$ & $\begin{array}{l}-0.153 \\
(0.233)\end{array}$ & $\begin{array}{l}-0.161 \\
(0.309)\end{array}$ & $\begin{array}{l}-0.073 \\
(0.327)\end{array}$ & $\begin{array}{l}-0.796 \\
(0.845)\end{array}$ \\
\hline Part of a group & $\begin{array}{c}0.241 * * * \\
(0.072)\end{array}$ & $\begin{array}{c}0.236 * * * \\
(0.072)\end{array}$ & $\begin{array}{c}0.247 \\
(0.157)\end{array}$ & $\begin{array}{l}-0.182 \\
(0.345)\end{array}$ & $\begin{array}{l}-0.256 \\
(0.210)\end{array}$ & $\begin{array}{l}-0.168 \\
(0.787)\end{array}$ \\
\hline Headquarter & $\begin{array}{c}0.407 * * * \\
(0.132)\end{array}$ & $\begin{array}{c}0.363 * * \\
(0.152)\end{array}$ & $\begin{array}{l}0.406^{*} \\
(0.244)\end{array}$ & $\begin{array}{l}-0.929^{*} \\
(0.482)\end{array}$ & $\begin{array}{c}-1.153 * * * \\
(0.446)\end{array}$ & $\begin{array}{l}-0.299 \\
(1.390)\end{array}$ \\
\hline Export 2008 & $\begin{array}{c}0.379 * * * \\
(0.076)\end{array}$ & $\begin{array}{c}0.375^{* * * *} \\
(0.073)\end{array}$ & $\begin{array}{c}0.376^{* *} \\
(0.149)\end{array}$ & $\begin{array}{c}0.159 \\
(0.333)\end{array}$ & $\begin{array}{c}0.102 \\
(0.321)\end{array}$ & $\begin{array}{c}0.443 \\
(0.854)\end{array}$ \\
\hline Patent 2008 & $\begin{array}{c}9.509 \\
(6.976)\end{array}$ & $\begin{array}{c}9.610 * * * \\
(12.86)\end{array}$ & $\begin{array}{c}7.743 \\
(4.708)\end{array}$ & $\begin{array}{c}0.941 \\
(0.637)\end{array}$ & $\begin{array}{c}0.735 \\
(0.518)\end{array}$ & $\begin{array}{c}3.701 * * \\
(1.749)\end{array}$ \\
\hline Public financial support & $\begin{array}{c}1.012 * * * \\
(0.074)\end{array}$ & $\begin{array}{c}0.967 * * * \\
(0.086)\end{array}$ & $\begin{array}{c}1.128 * * * \\
(0.198)\end{array}$ & $\begin{array}{c}1.351 * * * \\
(0.414)\end{array}$ & $\begin{array}{l}1.381^{* *} \\
(0.549)\end{array}$ & $\begin{array}{l}1.931 * * \\
(0.952)\end{array}$ \\
\hline Cost barriers & $\begin{array}{c}0.510 * * * \\
(0.093)\end{array}$ & $\begin{array}{l}0.335^{*} \\
(0.171)\end{array}$ & $\begin{array}{c}0.883 * * * \\
(0.140)\end{array}$ & $\begin{array}{c}0.297 \\
(0.424)\end{array}$ & $\begin{array}{c}0.371 \\
(0.478)\end{array}$ & $\begin{array}{c}0.291 \\
(1.329)\end{array}$ \\
\hline Knowledge barriers & $\begin{array}{l}-0.080 \\
(0.064)\end{array}$ & $\begin{array}{l}-0.100 \\
(0.072)\end{array}$ & $\begin{array}{l}-0.044 \\
(0.158)\end{array}$ & $\begin{array}{l}-0.031 \\
(0.208)\end{array}$ & $\begin{array}{l}-0.088 \\
(0.201)\end{array}$ & $\begin{array}{c}0.245 \\
(0.716)\end{array}$ \\
\hline Market barriers & $\begin{array}{c}0.011 \\
(0.079)\end{array}$ & $\begin{array}{c}0.028 \\
(0.099)\end{array}$ & $\begin{array}{l}-0.064 \\
(0.187)\end{array}$ & $\begin{array}{l}-0.254 \\
(0.268)\end{array}$ & $\begin{array}{l}-0.151 \\
(0.328)\end{array}$ & $\begin{array}{l}-0.679 \\
(0.491)\end{array}$ \\
\hline Regulation barriers & $\begin{array}{l}-0.115 \\
(0.074)\end{array}$ & $\begin{array}{l}-0.120 \\
(0.086)\end{array}$ & $\begin{array}{l}-0.125 \\
(0.142)\end{array}$ & $\begin{array}{l}-0.345 \\
(0.224)\end{array}$ & $\begin{array}{c}-0.649 * * \\
(0.294)\end{array}$ & $\begin{array}{c}0.869^{* * *} \\
(0.341)\end{array}$ \\
\hline Cooperation in innovation & & & & $\begin{array}{c}1.314 * * * \\
(0.260)\end{array}$ & $\begin{array}{c}0.937 * * * \\
(0.297)\end{array}$ & $\begin{array}{c}2.790 * * * \\
(0.531)\end{array}$ \\
\hline Market sources of information & & & & $\begin{array}{c}0.280 \\
(0.246)\end{array}$ & $\begin{array}{c}0.246 \\
(0.299)\end{array}$ & $\begin{array}{c}0.540 \\
(0.543)\end{array}$ \\
\hline Scientific sources of information & & & & $\begin{array}{l}-0.139 \\
(0.205)\end{array}$ & $\begin{array}{l}-0.184 \\
(0.285)\end{array}$ & $\begin{array}{l}-0.108 \\
(0.479)\end{array}$ \\
\hline Public sources of information & & & & $\begin{array}{l}-0.205 \\
(0.218)\end{array}$ & $\begin{array}{l}-0.101 \\
(0.230)\end{array}$ & $\begin{array}{l}-0.804 \\
(0.540)\end{array}$ \\
\hline
\end{tabular}




\begin{tabular}{|c|c|c|c|c|c|c|}
\hline Observations & 2,718 & 1,838 & 870 & 2,718 & 1,838 & 870 \\
\hline Prob > chi 2 & & & & 0.000 & 0.000 & 0.000 \\
\hline Log likelihood & & & & $-3,045.574$ & $-2,330$ & -699.144 \\
\hline Independence $(\boldsymbol{X}=0)$ & $1.620^{* *}$ & 1.980 & 0.11 & & & \\
\hline \multirow[t]{2}{*}{ Rho } & -0.273 & -0.323 & 0.208 & & & \\
\hline & 0.189 & 0.233 & 0.414 & & & \\
\hline \multirow[t]{2}{*}{ Sigma } & 2.753 & 2.780 & 2.565 & & & \\
\hline & 0.138 & 0.203 & 0.258 & & & \\
\hline \multirow[t]{2}{*}{ Lamda } & -0.751 & -0.898 & 0.535 & & & \\
\hline & 0.555 & 0.709 & 1.039 & & & \\
\hline \multirow[t]{2}{*}{ athrho } & & & & -0.280 & -0.335 & 0.212 \\
\hline & & & & $(0.205)$ & -0.261 & -0.434 \\
\hline \multirow[t]{2}{*}{ Lnsigma } & & & & $1.013^{* * *}$ & $1.023 * * *$ & $0.942 * * *$ \\
\hline & & & & -0.050 & -0.0731 & -0.101 \\
\hline
\end{tabular}

Notes: Standard errors in parentheses. Marginal effects are reported for engagement in innovation activities and for innovation intensity. Industry dummies are included in all equations

Significant: *** $\mathrm{p}<0.01, * * \mathrm{p}<0.05, * \mathrm{p}<0.1$

\section{Table 3: Probability of technological innovation}

\begin{tabular}{lccc}
\hline \multicolumn{1}{c}{ Dep. Variable } & \multicolumn{2}{c}{ Technology innovation dummy } \\
\hline Sample & Complete & Manufacturing & Services \\
Innovation intensity & $0.142^{* * *}$ & $0.164 * * *$ & $0.027 * * *$ \\
& $(0.005)$ & $(0.010)$ & $(0.005)$ \\
Firm FDI & 0.009 & -0.01 & 0.017 \\
& $(0.015)$ & $(0.025)$ & $(0.018)$ \\
Size 2009 $(\log )$ & -0.01 & -0.009 & -0.002 \\
& $(0.009)$ & $(0.010)$ & $(0.003)$ \\
Export 2008 & $0.056 * * *$ & $0.078 * * *$ & 0.004 \\
& $(0.017)$ & $(0.019)$ & $(0.012)$ \\
\hline Observations & 2,718 & 1,844 & 874 \\
Prob $>$ chi2 & 0.000 & 0 & 0.000 \\
Log likelihood & -818.309 & -684.22 & -825.736 \\
\hline
\end{tabular}


Notes: Standard errors in parentheses. Marginal effects are reported. Industry dummies are included.

Significant: $* * * \mathrm{p}<0.01, * * \mathrm{p}<0.05, * \mathrm{p}<0.1$

\section{Table 4: Impact of innovation on productivity}

\begin{tabular}{|c|c|c|c|c|c|c|}
\hline \multirow{4}{*}{$\begin{array}{l}\text { Dep. Variable } \\
\text { Sample } \\
\text { Technological innovation }\end{array}$} & \multicolumn{6}{|c|}{ Labor productivity } \\
\hline & \multicolumn{2}{|c|}{ Complete } & \multicolumn{2}{|c|}{ Manufacturing } & \multicolumn{2}{|c|}{ Services } \\
\hline & $1.205^{* * *}$ & & $1.176^{* * *}$ & & $1.073 * * *$ & \\
\hline & $(0.130)$ & & $(0.128)$ & & $(0.324)$ & \\
\hline \multirow[t]{2}{*}{ Innovation intensity } & & $0.188 * * *$ & & $0.171 * * *$ & & $0.103 * *$ \\
\hline & & $(0.029)$ & & $(0.029)$ & & $(0.045)$ \\
\hline \multirow[t]{2}{*}{ Size $2009(\log )$} & $-0.107 * * *$ & $-0.111 * * *$ & $-0.088 * *$ & $-0.085 * * *$ & $-0.147 * *$ & $-0.155 * * *$ \\
\hline & $(0.029)$ & $(0.030)$ & $(0.044)$ & $(0.033)$ & $(0.062)$ & $(0.052)$ \\
\hline \multirow[t]{2}{*}{ Non technological innovation } & $0.192 * * *$ & $0.216^{* * *}$ & $0.184 * * *$ & $0.206^{* * *}$ & $0.205 * *$ & $0.211 * *$ \\
\hline & $(0.036)$ & $(0.049)$ & $(0.055)$ & $(0.057)$ & $(0.086)$ & $(0.104)$ \\
\hline \multirow[t]{2}{*}{ Capital per employee } & $4.47 \mathrm{E}-06$ & $4.75 \mathrm{E}-06$ & $2 \mathrm{E}-05$ & $1.95 \mathrm{E}-05$ & $8.94 \mathrm{E}-07$ & $7.10 \mathrm{E}-07$ \\
\hline & $(0.000)$ & $(0.000)$ & $(0.000)$ & $(0.000)$ & $(0.000)$ & $(0.000)$ \\
\hline \multirow[t]{2}{*}{ Engineers in technical department } & $0.002 * * *$ & $0.002 * * *$ & $0.003 * *$ & $0.003 * * *$ & $0.001 * *$ & $0.001 * *$ \\
\hline & $(0.001)$ & $(0.001)$ & $(0.001)$ & $(0.001)$ & $(0.000)$ & $(0.000)$ \\
\hline \multirow[t]{2}{*}{ Constant } & $6.745 * * *$ & $6.657 * * *$ & $6.022 * * *$ & $5.909 * * *$ & $6.919 * * *$ & $7.274 * * *$ \\
\hline & $(0.349)$ & $(0.326)$ & $(0.343)$ & $(0.224)$ & $(0.396)$ & $(0.372)$ \\
\hline Observations & 2,718 & 2,718 & 1,844 & 1,844 & 874 & 874 \\
\hline \multirow[t]{2}{*}{ Sigma } & $1.158 * * *$ & $1.167 * * *$ & $1.092 * * *$ & $1.101 * * *$ & $1.284 * * *$ & $1.288 * * *$ \\
\hline & $(0.024)$ & $(0.024)$ & -0.026 & -0.027 & -0.043 & -0.038 \\
\hline Prob $>$ chi 2 & 0.000 & 0.000 & 0 & 0 & 0 & 0 \\
\hline Pseudo R2 & 0.075 & 0.071 & 0.074 & 0.069 & 0.035 & 0.033 \\
\hline Log likelihood & -4256.86 & -4277 & -2778.902 & -2794.545 & -1459.083 & -1461.673 \\
\hline
\end{tabular}

